\title{
The Impact of Ineffective ITG on IT Deployment: A Study of Failed IT Deployment Initiatives
}

\author{
Mehdi Asgarkhani \\ Department of Computing \\ Ara Institute of Canterbury \\ Christchurch, New Zealand \\ Email: Mehdi.Asgarkhani@ara.ac.nz
}

Mark Toleman

School of Management and Enterprise

University of Southern Queensland (USQ)

Toowoomba, Australia

Email: Mark.Toleman@usq.edu.au

\section{Mustafa Ally}

School of Management and Enterprise

University of Southern Queensland (USQ)

Springfield, Australia

Email: Mustafa.Ally@usq.edu.au

\section{Michael Lane}

School of Management and Enterprise

University of Southern Queensland (USQ)

Toowoomba, Australia

Email: Michael.Lane@usq.edu.au

\section{Abstract}

Organisations continue to make significant investments in Information Technology (IT) to enable business. To ensure a return on investment in IT, there is a need for a wider accountability focus on strategic technology initiatives alongside a structured and evaluative approach to the effective governance of IT. Throughout the last decade, systems, processes, standards and best practice frameworks have been developed to facilitate effective IT governance. However, IT deployment initiatives seem to continue to fail to deliver outcomes. This paper examines the impact of ineffective IT governance (ITG) on IT deployment failure in a set of failed IT projects. First, a literature review establishes the influencers (and indicators) of effective ITG. Next, a multiple case study analysis of failed IT deployment initiatives identifies key contributors to deployment failure. Finally, the outcome of the case study analysis is mapped back to the indicators of effective ITG derived from the literature review to determine a possible connection between failed IT deployment and ineffective IT governance. The outcome of the analysis demonstrates a connection between project failures and lack of effective ITG.

Keywords: Information Technology (IT) Governance (ITG), Effectiveness of ITG, Evaluating ITG Effectiveness, Model of ITG Effectiveness, IT Project Failure, IT Deployment Case Studies. 


\section{Introduction}

Today, Information Technology (IT) solutions play a significant role in enabling businesses. Organisations commit considerable funds to both capital and operational expenses to deploy and operate IT solutions (Lovelock et al., 2016; McLellan, 2014). Deploying technology is often associated with significant organisational change. The change can be associated with significant risks (Davis et al., 1997; EDUCAUSE centre for applied research, 2008; Gauld and Goldfinch, 2006; Laudon and Laudon, 2014).

Despite significant technology advancements and increased awareness of technology management, there are IT deployment cases where organisational outcomes are not materialised (Gole and Shinsky, 2013). For instance, some of the recent case studies of challenged IT deployment initiatives (where deployment of technology failed to deliver the expected outcomes) include the Queensland Health project (Chesterman, 2013), the WINZ NZ kiosk security failure (Deloitte, 2012; Data, 2011) and the NOVOPAY project (NZ Government, 2013).

Increased investment in IT has meant that there is an expectation by organisations that they not only maximise the benefits of adopting IT but also avoid the drawbacks and risks that are often associated with the rapid introduction of technological change (Asgarkhani, 2013; Van Grembergen, 2004). IT practitioners and managers, as well as IT strategists and planners, have continuously developed and put into practice improved IT deployment decision-making processes. Throughout this paper, the term 'practitioner' applies to those who take a deployed system (solution) view when they examine effectiveness. 'Strategists' are those who examine the future direction of an organisation concerning IT deployment and the role and impact of IT Governance (ITG) in securing value from future IT deployments.

Previous studies have shown that IT is expected to add value to the organisation through improved productivity, increased efficiency and profitability, better communication, more effective decision making and higher customer satisfaction (Larcker and Tayan, 2008a). Moreover, studies show that to maximise benefits and value gained from investment in IT, it is universally acknowledged that IT must be fully aligned with overall business strategies and direction (Asgarkhani, 2013; Van Grembergen, 2004). Considerable organisational resources are consumed to manage how IT is acquired and diffused in organisations (Weill and Ross, 2004b; Wu et al., 2015). ITG consists of leadership, organisational structures, and processes which ensure that the enterprise's IT sustains and extends the organisation's strategies and objectives (ITGI, 2007). ITG frameworks and standards were introduced to organisations in the 1990s (Brown and Magill, 1994; Cater-Steel et al., 2006; De Haes and Van Grembergen, 2006; Van Grembergen and De Haes, 2009; Fukuyama, 2013).

The literature on ITG provides advice and recommendations on models and frameworks for ITG implementation (De Haes and Van Grembergen, 2010; Van Grembergen and De Haes, 2009; Weill and Ross, 2004b; Weill and Vitale, 2002; Williams, 2012). The literature outlined in the paper suggests that previous studies on ITG tend to assume that recommended models and practices lead to effective governance, although we could find no empirical evidence to support this assumption. More specifically, despite the number of prescriptive models and 'best practice frameworks' available, and increased uptake of ITG in organisations, achieving effective ITG outcomes is consistently ranked as one of the top concerns of management (Gartner, 2016).

The research problem that motivated this study can be described as determining why, despite the availability of numerous recommended 'best practice frameworks' and models of effective ITG, a significant number of IT deployment projects fail to deliver value.

Two broad research questions motivated this study:

- What influences and indicates the effectiveness of ITG practices?

- What contributes to the failure of IT deployment projects?

- Is there a connection between ineffective ITG and failed IT deployment initiatives?

The paper presents the results of the literature review aimed at determining the influencers (and indicators) of ITG effectiveness - forming a broad conceptual model for ITG effectiveness. Next, six case studies of failed IT deployment projects were analysed to determine the causes of failure. The causes of failure were mapped to the influencers of ITG effectiveness (from the literature review also acting as 
indicators of the existence of good ITG practice) to examine the connection between failed projects and the role of ITG.

The paper begins with the literature review presenting the analysis of previous studies with a focus on determining influencers of ITG effectiveness. The literature review is followed by the methodology for the study and the selection of case studies for analysis. The methodology section is followed by the analysis of the case studies and discussion of outcomes. Finally, the conclusion provides a summary of the study and discusses the contribution, limitations and future planned research.

\section{Literature Review}

The purpose of the literature review is to identify (based on previous research) factors that influence and indicate effective ITG. The literature review guided the development of a model of factors that are likely to influence (and also demonstrate) effective ITG (Bem, 1995; Baumeister and Leary, 1997; Moher et al., 2009; Okoli, 2015; Bakker, 2010). The first step of the literature review involved the selection of eligible articles. The preliminary search for resources included journals, and quality assured conference proceedings repositories (such as Science Direct, Springer Link, IEEE Xplore Digital Library, Emerald, Taylor \& Francis), books, reports by IT sector professional bodies (for instance Institute of IT Professionals NZ, Australian Computer Society, and British Computer Society), governmentcommissioned reports, google scholar, and universities' investigative reports.

Key phrases used for the initial search included Information Technology Governance, IT Governance, IT solutions deployment, IT deployment success, IT Deployment failure, IT Governance effectiveness, IT Governance practices, IT Governance Standards/Models, IT Governance Success Factors, IT Governance Mechanisms, IT solutions success/failure, IT Governance theory, IT development, IT platforms changes, Technology changes, and Technology solutions. A logical OR was adopted to search using the phrases above. More specifically, articles that referred to any of the phrases listed were considered in the initial search.

The initial search of qualifying publications and articles resulted in 189 articles although on further analysis some abstracts, titles, and conclusions did not provide a clear understanding of the purpose of the articles. Therefore, a more detailed analysis of the articles was necessary. The introduction, background, and methodology sections were examined. The examination of titles, abstracts, conclusions, introduction, and the methodology sections identified similar or duplicated results that were excluded. After the completion of the screening process, the number of eligible articles was reduced to 71 .

In general, the analysis of the literature suggested that the theoretical foundations of Agency Theory (Bonazzi and Islam, 2007; McColgan, 2001), with a strong focus on control, predominantly underpin the current ITG practices. Moreover, effective ITG practices are more likely to secure value delivery of IT deployment (DeLone \& McLean, 1992; Weill \& Vitale, 2002; Van Grembergen, 2004; Weill \& Ross, 2004; De Haes \& Van Grembergen, 2010). The literature showed that previous researchers agree in general that effective ITG leads to successful deployment of IT. However, there are two different approaches to substantiating effective ITG (DeLone \& McLean, 1992; DeLone \& McLean, 2003; Van Grembergen, 2004).

The first group of researchers (Delone \& McLean, 2003; Esteves \& Joseph, 2008; Halonen, Acton, Golden, \& Conboy, 2009) argued that successfully deployed information systems and applications could indicate effective strategic management of technology deployment. They focussed on operational and tactical issues and recommended models to measure the success of information systems to reflect effective ITG.

The second group (Van Grembergen and De Haes, 2009; Van Grembergen, 2004; Weill and Ross, 2004b) argued that factors that can be examined to assess ITG effectiveness are related to strategic approaches, relational mechanisms, and use of standards and frameworks that are expected to lead to ITG effectiveness. They examined and recommended strategic factors that could influence the effectiveness of ITG.

Next, to determine the indicators of effective ITG (taking into account both views above), a conceptcentric qualitative analysis (Webster and Watson, 2002) of eligible articles was performed. The analysis determined that previous research outlines various factors that could indicate (and influence) effective ITG, for instance, the existence of an IT steering committee or evidence of monitoring and the assessing of value returned from decisions made on deploying IT. 
The set of factors identified seemed to relate to various broader themes of influencers and indicators of effective ITG. Therefore, with reference to broader views expressed by both strategists (Van Grembergen and De Haes, 2009; Van Grembergen, 2004; Weill and Ross, 2004a) and practitioners (DeLone and McLean, 1992; Delone and McLean, 2003; Van Grembergen, 2004) the set of identified influencers were further analysed, and related influencers were placed in broader categories. The grouping identified eight key groups of influencers including Decision-Making Structure, Formalised systems and processes, Effective communication, Business outcome orientated IT, Alignment of organisational quality-orientated strategies with strategies for the use of IT solutions, the history and the current state of IT deployment, Awareness of organisations financial performance supported by IT solutions, and Operational excellence influenced by the deployment of IT.

Moreover, further examination of both strategists' and practitioners' views (De Haes and Van Grembergen, 2010; Van Grembergen, 2004; Weill and Vitale, 2002; Weill and Ross, 2004b; Delone and McLean, 2003; DeLone and McLean, 1992), determined three broad strategic themes that could highlight and indicate ITG effectiveness: ITG Maturity, Alignment of IT and Business, and Organisational Performance influenced by IT deployment.

Table 1 summarises the outcome of the literature review as a model of influencers and indicators of effective ITG.

Table 1. Themes of the indicators and influencers of ITG effectiveness

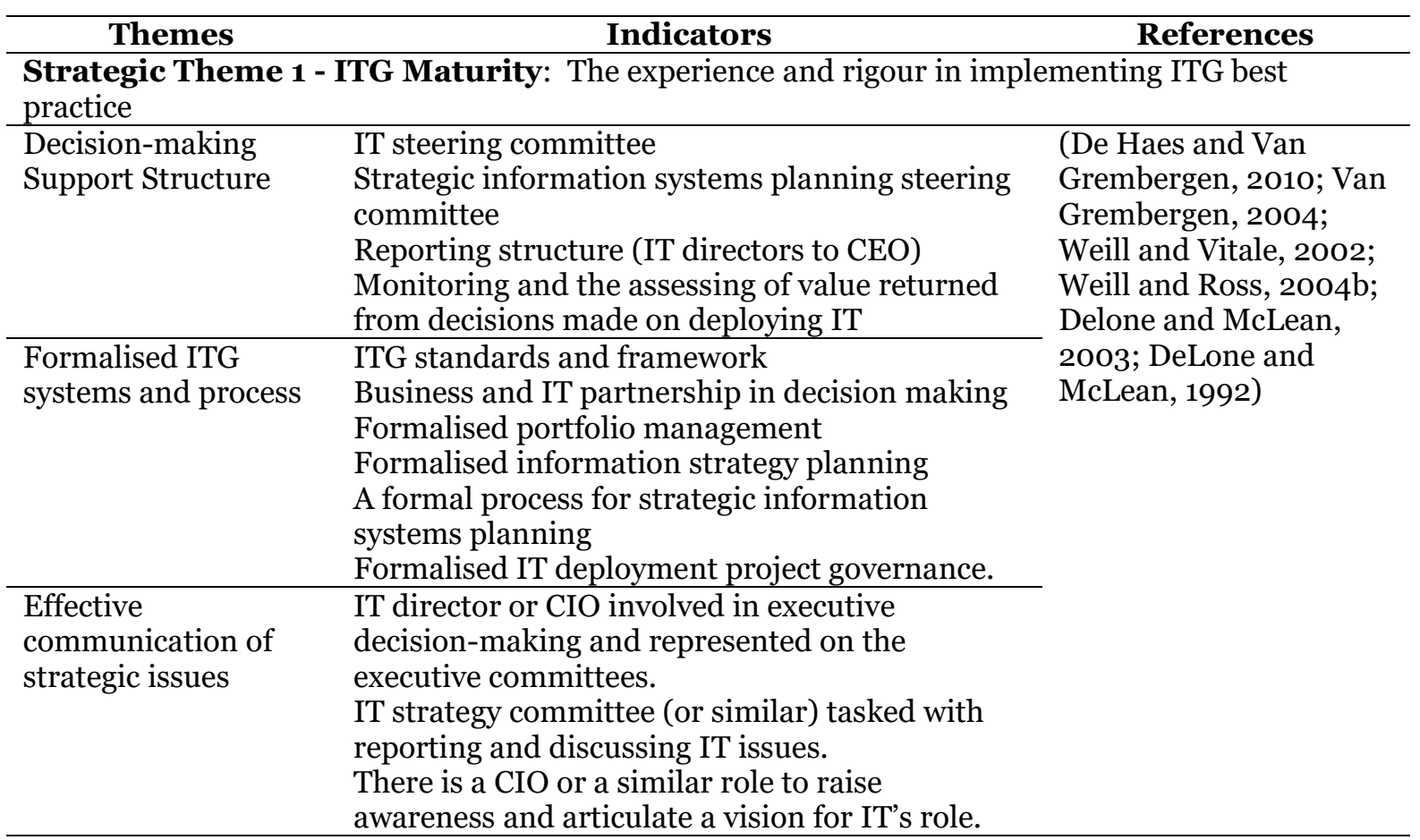

Strategic Theme 2 - Strategic Alignment of IT and Business: The connection and coherence between fulfilling business strategy and the IT strategy.

\begin{tabular}{|c|c|c|}
\hline $\begin{array}{l}\text { Business outcome- } \\
\text { orientated alignment } \\
\text { of IT and Business }\end{array}$ & $\begin{array}{l}\text { IT strategies recognise and support new } \\
\text { business outputs (products and services) } \\
\text { Technology support for business outcome } \\
\text { diversification strategies } \\
\text { Technology and service support for business } \\
\text { outcome differentiation. }\end{array}$ & $\begin{array}{l}\text { (De Haes and Van } \\
\text { Grembergen, 2010; Van } \\
\text { Grembergen, 2004; Van } \\
\text { Grembergen and De } \\
\text { Haes, 2009; Weill, } \\
\text { 2004; Kaplan and }\end{array}$ \\
\hline $\begin{array}{l}\text { Alignment of } \\
\text { organisational } \\
\text { quality-orientated } \\
\text { strategies with } \\
\text { strategies for the use }\end{array}$ & $\begin{array}{l}\text { Adoption of IT Solutions supports business } \\
\text { outcome (products and services quality) } \\
\text { including production and marketing. }\end{array}$ & $\begin{array}{l}\text { Norton, 2004; Kaplan, } \\
\text { 2010; Prasad et al., } \\
\text { 2008; Myers, 2012; } \\
\text { Ramgovind et al., 2015) }\end{array}$ \\
\hline
\end{tabular}
of IT solutions. 


\section{Themes}

Indicators

References

\begin{tabular}{|c|c|c|}
\hline Themes & Indicators & References \\
\hline \multicolumn{3}{|c|}{$\begin{array}{l}\text { Strategic Theme } 3 \text { - Organisational Performance influenced by technology } \\
\text { deployment: Organization's overall performance and delivery of outcomes supported by IT } \\
\text { relative to its competition }\end{array}$} \\
\hline $\begin{array}{l}\text { The history and the } \\
\text { current state of IT } \\
\text { deployment within } \\
\text { an organisation }\end{array}$ & $\begin{array}{l}\text { The current level of process automation via IT } \\
\text { User acceptance of technology solutions } \\
\text { Support mechanisms for IT solutions } \\
\text { Timely delivery of relevant information for } \\
\text { effective decision making } \\
\text { Effective service management of IT solutions }\end{array}$ & $\begin{array}{l}\text { (DeLone and McLean, } \\
\text { 1992; Delone and } \\
\text { McLean, 2003; Esteves } \\
\text { and Joseph, 2008; } \\
\text { Halonen et al., 2009; } \\
\text { Zaied, 2012; Hellsten }\end{array}$ \\
\hline $\begin{array}{l}\text { Awareness of } \\
\text { organisations } \\
\text { financial } \\
\text { performance } \\
\text { supported by IT } \\
\text { solutions }\end{array}$ & $\begin{array}{l}\text { Processes for monitoring an organisation's } \\
\text { performance } \\
\text { Metrics such as return on investment used to } \\
\text { assess value delivery of IT }\end{array}$ & and Karkove, 2006) \\
\hline $\begin{array}{l}\text { Operational } \\
\text { excellence influenced } \\
\text { by the deployment of } \\
\text { IT }\end{array}$ & $\begin{array}{l}\text { The existence of processes and metrics for } \\
\text { operational performance } \\
\text { Seeking ongoing productivity improvements via } \\
\text { the deployment of technology solutions } \\
\text { Service level agreements and timeline for service } \\
\text { delivery }\end{array}$ & \\
\hline
\end{tabular}

The term indicator is used alongside indicators in the literature review consistently. An influencer is referring to the factors that previous research highlights that influence good practice ITG. The existence (or lack of it) of the same factors is seen as the evidence of good practice (or lack of it) in case studies.

\section{Research Methodology}

Multiple case studies were analysed to identify the possible connection between IT deployment failure and ineffective ITG. Case study analysis has been recommended as a suitable methodology for qualitative studies where contextual analysis adds value to the study (Baxter and Jack, 2008; Stake, 2006; Ritchie and Lewis, 2003; Yin, 2011). Sources for the selection of the case studies included MIS Quarterly, Gartner Research (www.gartner.com), publications by the British Computer Society, Australian Computer Society, Institute of IT Professionals NZ, New Zealand and Australian Government (IT projects publications), and the CIOIndex (www.cioindex.com). The selection criteria included: The complexity of the project (the impact of the project on both major strategic and operational functions), The cost of the project (at least AUD \$20M), Geographic location (projects from various English speaking countries including New Zealand, Australia, Europe, and North America), Timeframe (no older than 10 years), and Availability of sufficient information for analysis.

Failure: Failed projects identified as deployment initiatives missing targets (timelines, cost, and functionality) by approximately $20 \%$ or more. All projects included application development or deployment. Most projects required some technology platform or infrastructure changes.

Six case studies were selected for analysis. They included: New Zealand's NovoPay (NZ Government Internal Affairs, 2014), Victoria's (Australia) HealthSMART (Brouwer, 2011), UK's IT in NHS (Campion-Awwad et al., 2014), Canada's Phoenix project (Barnhart et al., 2013), HP's ERP Implementation (Chaluverdi and Gupta, 2005) and JetSmart Qantas (Krigsman, 2008).

An emergent coding approach (no pre-set codes defined) was employed to analyse the selected case studies of IT deployment failure (Fereday and Muir-Cochrane, 2016; Swain, 2018). Events and developments that contributed to the outcome of the project were extracted and added as excerpts into Dedoose (a web-based qualitative analysis tool). The excerpts were further analysed and coded into factors that contributed to the failure of projects. 


\section{Analysis of Case Studies}

The literature review determined three main groups of factors that both influence and indicate effective ITG. The analysis of failed IT deployment initiatives is intended as determining a possible link between failed IT deployments and lack of effective ITG. The analysis of the factors that contributed to the failure of IT deployment was done independently of the literature review outcomes (Cenfetelli, 2004).

A concept-centric qualitative analysis of the excerpts from all cases resulted in identifying 26 contributors to IT deployment failure: implementation difficulties, lack of sufficient training or IT skills, inadequate test planning and testing, lack of sufficient resource, data migration failure, slow adoption of technology, lack of executive oversight, confused roles accountability, lack of stakeholder involvement, poor user understanding of technology, poor design (functionality \& usability), poor day to day project management, conflicting or dysfunctional leadership, poor risk and contingency planning, lack of business case, unrealistic goals and expectations, poor scope definition (scope creep), lack of risk assessment, poor relationship management of parties involved, unprofessional, poor processes and practices, ineffective communication, lack of flexibility of models or frameworks applied, unrealistic and unnecessary pressure on project teams, lack of role clarity, complexity of design and functionality, and inadequate change management.

Further analysis of the 26 identified contributors showed that they could be related to broad phases or events throughout the process. For instance, the lack of adequate testing or poor data migration relates to the phase when technology is implemented. Similarly, lack of stakeholder involvement, poor design, lack of a business case, unrealistic goals, inadequate scope management, and poor communication, is connected with risk and change management (Delone and McLean, 2003; DeLone and McLean, 1992). Therefore, the 26 identified contributors were placed into eight broader groups of contributors to failure - table 2.

The outcome of the analysis demonstrated two points. First, the contributors to the failure of IT deployment seemed to connect more directly to 'project management' issues rather than strategic ITG matters. However, considering the key domains of ITG, even operational project management problems can directly or indirectly be associated with lack of effectiveness in one of ITG domains. Moreover, establishing a connection between failed IT deployments, and ineffective ITG proved more complex than anticipated.

As outlined earlier, the analysis of the previous research and the study of cases of failed IT deployments were conducted independently. To ascertain a possible connection between failed IT deployment and ineffective ITG, there is a need to map the outcomes of the literature review (Table 1) and case study analysis (Table 2).

The approach undertaken involved the analysis of the contributors to IT deployment failure to determine if they could relate to any influencers and indicators of effective ITG. More specifically, the mapping involved determining if the identified contributor to failure could have been avoided by the existence of any effective ITG influencer/indicator (Cenfetelli, 2004). For instance, poor Implementation Management (as a theme contributing to failure - table 2) involves poor testing, technical know-how, poor data migration, unnecessary pressure on people, and poor change management. Table 1 was examined to determine if the lack of any influencers or indicators could connect to the causes of poor implementation management. It was observed that some of the indicators of the strategic theme 3 (Organizational Performance - table 1) could impact on contributors to poor implementation management. More specifically, lack of support mechanisms for IT solutions, effective service management of IT solutions, processes for monitoring organisation's performance, the existence of processes and metrics for operational performance, and service level agreements and timeline for service delivery influence contributors to failure identified as poor implementation management. Therefore, poor implementation management (based on the sample of projects examined) is influenced by ineffective ITG as related to strategic theme 3 (Organizational Performance). 
Table 2. Themes of contributory factors to IT deployment failure

\begin{tabular}{|c|c|}
\hline $\begin{array}{c}\text { Identified themes } \\
\text { ( } 8 \text { broad areas of failure }- \text { six case studies) }\end{array}$ & $\begin{array}{l}\text { Sub-themes - Contributing } \\
\text { Factors ( } 26 \text { initial factors) }\end{array}$ \\
\hline $\begin{array}{l}\text { Implementation management } \\
\text { Sample extracts } \\
\text { The IT personnel were subjected to the new technology without having } \\
\text { adequate time to develop their skills for the new system } \\
\text { HP's ERP }\end{array}$ & $\begin{array}{l}\text { Testing, technical know-how, data } \\
\text { migration, unnecessary pressure on } \\
\text { people, lack of training, and change } \\
\text { management }\end{array}$ \\
\hline $\begin{array}{l}\text { Resources management (including people) } \\
\text { Sample extracts } \\
\text { The IT personnel were subjected to the new technology without having } \\
\text { adequate time to develop their skills for the new system } \\
\text { HP's ERP } \\
\text { By June 2013, Lorenzo had been delivered on ten sites (out of a } \\
\text { contracted 166), of which seven were running them off the shelf } 1.0 \\
\text { version as an interim solution. Three other sites were running the } \\
\text { desired 1.9 version but not with satisfactory functionality } \\
\text { UK'S IT in NHS }\end{array}$ & $\begin{array}{l}\text { Lack of training, limited skills, } \\
\text { unnecessary pressure, and slow } \\
\text { adoption of technology }\end{array}$ \\
\hline $\begin{array}{l}\text { Accountability and clarity of roles } \\
\text { Sample extracts } \\
\text { There was significant turnover in key project positions } \\
\text { Until late in the project, there was no programme director with } \\
\text { accountability across the whole project } \\
\text { NovaPay }\end{array}$ & $\begin{array}{l}\text { Lack of broader governance and } \\
\text { executive oversight, confused } \\
\text { accountability, relationship } \\
\text { management, and role clarity }\end{array}$ \\
\hline $\begin{array}{l}\text { IT-Business alignment } \\
\text { Sample extracts } \\
\text { The relationship between the Ministry and Talent2 was not sufficiently } \\
\text { constructive to manage the underlying risks } \\
\text { NovaPay }\end{array}$ & $\begin{array}{l}\text { Slow adoption of technology, lack of } \\
\text { executive oversight, confused } \\
\text { accountability, dysfunctional } \\
\text { leadership, stakeholder engagement, } \\
\text { risk management, unprofessional } \\
\text { practices, and lack of flexibility, } \\
\text { unnecessary pressure }\end{array}$ \\
\hline $\begin{array}{l}\text { Information Technology Leadership } \\
\text { Sample extracts } \\
\text { The IT personnel were subjected to the new technology without having } \\
\text { adequate time to develop their skills for the new system } \\
\text { HP's ERP } \\
\text { "As long as people enter [information] wrong, it will be wrong. It could } \\
\text { be wrong ten years from now. To do it over again, I would have made } \\
\text { training absolutely mandatory" - Rosanna Di Paola (associate } \\
\text { assistant deputy minister responsible for the federal)" } \\
\text { Phoenix }\end{array}$ & $\begin{array}{l}\text { Lack of understanding of the use of IT, } \\
\text { lack of IT skills, insufficient IT } \\
\text { resources, slow adoption of technology, } \\
\text { poor planning, lack of a business case, } \\
\text { lack of flexibility in approaches to use of } \\
\text { IT, lack of role clarity, poor change } \\
\text { management }\end{array}$ \\
\hline $\begin{array}{l}\text { Design and functionality } \\
\text { Sample extracts } \\
\text { Problems surfaced between the legacy system and the new SAP system } \\
\text { being implemented, as soon as the implementation went live } \\
\text { HP's ERP }\end{array}$ & $\begin{array}{l}\text { Data migration, lack of stakeholder } \\
\text { involvement, poor understanding of } \\
\text { technology, poor understanding of } \\
\text { functionality, unrealistic expectations, } \\
\text { scope creep, poor communication, and } \\
\text { complexity }\end{array}$ \\
\hline $\begin{array}{l}\text { Risk and change management } \\
\text { Sample extracts } \\
\text { A senior official responsible for rolling out the federal government's } \\
\text { Phoenix payroll system told a labour tribunal on Wednesday the issues } \\
\text { that led to pay problems for some 8o,ooo employees are due to a lack } \\
\text { of training, not the software itself." - CBC News } \\
\text { "As long as people enter [information] wrong, it will be wrong. It could } \\
\text { be wrong ten years from now. To do it over again, I would have made }\end{array}$ & $\begin{array}{l}\text { Inadequate testing, lack of stakeholder } \\
\text { involvement, poor design, lack of a } \\
\text { business case, unrealistic goals, } \\
\text { inadequate scope management, poor } \\
\text { communication, and complexity }\end{array}$ \\
\hline
\end{tabular}




\begin{tabular}{|l|l|}
\hline \multicolumn{1}{|c|}{$\begin{array}{c}\text { Identified themes } \\
\text { (8 broad areas of failure - six case studies) }\end{array}$} & \multicolumn{1}{|c|}{$\begin{array}{c}\text { Sub-themes - Contributing } \\
\text { Factors (26 initial factors) }\end{array}$} \\
\hline $\begin{array}{l}\text { training absolutely mandatory" - Rosanna Di Paola (associate } \\
\text { assistant deputy minister responsible for the federal)" } \\
\text { Phoenix }\end{array}$ & \\
\hline Use of standardised processes and practices & $\begin{array}{l}\text { Inadequate test planning, data } \\
\text { migration challenges, lack of } \\
\text { governance processes, unprofessional } \\
\text { practices (testing, communication), lack } \\
\text { of flexible processes, poor change } \\
\text { management processes }\end{array}$ \\
$\begin{array}{l}\text { Sample extracts } \\
\text { The ITpersonnel were subjected to the new technology without having } \\
\text { adequate time to develop their skills for the new system } \\
\text { HP's ERP }\end{array}$ & \\
$\begin{array}{l}\text { Failure to cleanse data before migration to the new system } \\
\text { Phoenix }\end{array}$ & \\
\hline
\end{tabular}

Similarly, lack of Accountability and Clarity of Roles (table 2) involves a lack of broader governance and executive oversight, confused accountability, relationship management, and role clarity. Once again, table 1 was examined to establish a connection between any effective ITG influencer and the identified contributor to failure (accountability and clarity or roles). It was noticed that some of the indicators of the strategic theme 1 (Organizational Maturity - table 1) could impact on contributors to lack of accountability and clarity of roles. In other words, the absence of process standards and frameworks, business and IT partnership in decision making (defining roles), a formalised portfolio management (roles), a formalised IT deployment project governance, IT strategy committee (or similar) tasked with reporting and discussing IT issues, and a CIO or a similar role to raise awareness and articulate a vision for IT and decision making roles are likely to influence contributors to failure related to lack of role clarity and accountability.

Table 3 outlines the outcome of mapping all contributors to failure from table 2 to influencers of ITG effectiveness. More specifically, the table outlines the lack of which broader themes of influencers could have been associated with the eight themes of contributors to failure. Table 3 suggests that the contributors to as determined by the study of six IT deployment initiatives show a connection with poor ITG.

Table 3 Mapping of the eight areas of contributors to factors to the absence of effective ITG3influencers

\begin{tabular}{ll}
\hline \multicolumn{1}{c}{$\begin{array}{c}\text { Identified themes } \\
\text { (8 broad areas of failure }- \text { six case studies } \\
\text { table } 2 \text { ) }\end{array}$} & $\begin{array}{c}\text { Reference the broad themes of } \\
\text { indicators of effective ITG } \\
\text { (Table } 1 \text { - literature review) }\end{array}$ \\
\hline Implementation management & ITG - organisational performance \\
\hline Resources management (including people) & ITG - organisational performance \\
\hline Accountability and clarity of roles & ITG - organisational maturity \\
& ITG - IT and Business Alignment \\
\hline IT-Business alignment & ITG - IT and Business alignment \\
& ITG - organisational maturity \\
\hline Information Technology Leadership & ITG - organisational maturity \\
& ITG - organisational performance \\
\hline Design and functionality & \\
\hline Risk and change management & ITG - organisational maturity \\
& ITG - organisational performance \\
\hline Use of standardised processes and practices & ITG - organisational maturity \\
& ITG - IT and business alignment \\
& ITG - organisational performance \\
\hline
\end{tabular}


Next, individual projects (cases) were examined to determine the extent of the presence of contributors to failure - as outlined in table 4 .

Table 4 demonstrates that Novo Pay and IT in NHS exhibited all eight areas of failure and therefore showing a connection to all three themes of ITG effectiveness. More specifically, lack of organisational maturity, poor IT and business alignment, and fragile organisational performance could have contributed to the failure of the two specific projects. Four areas of failure were present in all four cases: implementation management, IT-business alignment, risk and change management, and the use of standardised processes and practices. Four projects did not connect to all areas of failure.

In summary, overall, Table 4 suggests that the IT deployment failure in cases studies that were analysed seem to be associated with lack of the three themes of practices that influence effective ITG.

Table 4. Summary of Case Study Analysis Change the title

\begin{tabular}{|c|c|c|c|c|c|c|}
\hline  & NovoPay & $\begin{array}{c}\text { JetSmart } \\
\text { Project } \\
\text { (Qantas) }\end{array}$ & $\begin{array}{l}\text { ERP at } \\
\text { HP }\end{array}$ & HealthSMART & $\begin{array}{l}\text { IT in } \\
\text { NHS }\end{array}$ & Phoenix \\
\hline $\begin{array}{l}\text { Implementation } \\
\text { Management }\end{array}$ & $\sqrt{ }$ & $\sqrt{ }$ & $\sqrt{ }$ & $\sqrt{ }$ & $\sqrt{ }$ & $\sqrt{ }$ \\
\hline $\begin{array}{l}\text { Resources } \\
\text { Management }\end{array}$ & $\sqrt{ }$ & - & $\sqrt{ }$ & - & $\sqrt{ }$ & $\sqrt{ }$ \\
\hline $\begin{array}{l}\text { Accountability and } \\
\text { clarity of roles }\end{array}$ & $\sqrt{ }$ & $\sqrt{ }$ & - & $\sqrt{ }$ & $\sqrt{ }$ & - \\
\hline $\begin{array}{l}\text { IT-Business } \\
\text { alignment }\end{array}$ & $\sqrt{ }$ & $\sqrt{ }$ & $\sqrt{ }$ & $\sqrt{ }$ & $\sqrt{ }$ & $\sqrt{ }$ \\
\hline $\begin{array}{l}\text { Information } \\
\text { Technology } \\
\text { Leadership }\end{array}$ & $\sqrt{ }$ & $\sqrt{ }$ & - & - & $\sqrt{ }$ & $\sqrt{ }$ \\
\hline $\begin{array}{l}\text { Design and } \\
\text { functionality }\end{array}$ & $\sqrt{ }$ & $\sqrt{ }$ & $\sqrt{ }$ & - & $\sqrt{ }$ & $\sqrt{ }$ \\
\hline $\begin{array}{l}\text { Risk and change } \\
\text { management }\end{array}$ & $\sqrt{ }$ & $\sqrt{ }$ & $\sqrt{ }$ & $\sqrt{ }$ & $\sqrt{ }$ & $\sqrt{ }$ \\
\hline $\begin{array}{l}\text { Use of } \\
\text { standardised } \\
\text { processes and } \\
\text { practices }\end{array}$ & $\sqrt{ }$ & $\sqrt{ }$ & $\sqrt{ }$ & $\sqrt{ }$ & $\sqrt{ }$ & $\sqrt{ }$ \\
\hline
\end{tabular}

\section{Conclusions}

The study outlined in this paper has a focus on determining the connection between IT deployment failure and poor ITG practices. The study was conducted in two phases.

A broad analysis of the literature on ITG effectiveness suggested that despite previous studies on ITG (recommending options and approaches for improved deployment of IT), there is a lack of research on ITG effectiveness. There seems to be fragmentation in studies on ITG effectiveness with a focus on relevant but isolated issues (mechanisms, relationships, and system performance). The review highlights a need for integrated studies of ITG effectiveness. The analysis of the selected publications also indicated that there is a consensus among both practitioners and strategists that effective ITG is more likely to secure value from IT deployment. Further and a more focused analysis of the selected 71 articles determined that there are two schools of thought concerning the effectiveness of ITG. Information Systems (IS) academics and practitioners argued that successfully deployed information systems and applications could indicate effective strategic management of technology deployment. They focus on operational and tactical matters and recommend models for measuring the success of information systems to reflect effective ITG. On the other hand, strategists suggest that effectiveness of ITG can be assessed via strategic approaches, relational mechanisms, and the use of standards and frameworks. The analysis of literature identified 27 influencers (and indicators) of ITG effectiveness grouped into three strategic views of effectiveness: ITG maturity, strategic alignment of IT and business, and organisational performance influenced by technology deployment. 
The multiple case study analysis of six failed IT deployments was focused on firstly determining the contributors to failure and second connecting the contributors to the model of influencers and indicators of effective ITG (Table 1). The analysis of case studies determined eight main groups of factors that contributed towards the failure of IT deployment (table 2).

To answer the research question (How do poor ITG practices contribute to the failure of IT deployment initiatives?) the results of the case study analysis (table 2) were mapped to the model of influencers of ITG derived from the literature review (table 1). The mapping suggested that any of the eight areas of failure identified related to the ineffectiveness in at least one of the main strategic themes of influencers of effective ITG - as outlined in table 3 . This study contributes to the theory of ITG by identifying the categories of influencers of ITG effectiveness - as outlined in Table 3. For practitioners, the results of the study present a guide (set of contributors to failure and influencers of ITG effectiveness) for assessing the likelihood of project success before a deployment project is launched.

For future research, there are advantages to extending the number of case studies that are studied. Despite in-depth analysis of every case study and consideration of criteria that ensured inclusion of projects from various regions involving various solutions, analysis of an extended set of projects including analysis of cases of successful deployment projects can strengthen the findings of the study. Moreover, for future research, interviews with ITG practitioners and strategists can provide a third method of analysis thus providing a stronger triangulation of results from three sources of data.

\section{References}

Asgarkhani, M. Corporate ICT governance: A tool for ICT best practice. International Conference on Management, Leadership and Governance, 2013 Bangkok. ACL, 1-8.

Bakker, R. M. 2010. Taking stock of temporary organisational forms: A systematic review and research agenda. International Journal of Management Reviews, 12(4).

Barnhart, D., Sullivan, B., Hunter, R., Bruhn, J., Fowler, E., Hoag, L. M., Chappie, S., Henshaw, G., Kelm, B. E., Kennedy, T., Mook, M. \& Vincent, K. 2013. Phoenix Program Status - 2013. AIAA SPACE 2013 Conference and Exposition, AIAA SPACE Forum, (AIAA 2013-5341).

Baumeister, R. F. \& Leary, M. R. 1997. Writing narrative literature reviews. Review of General Psychology, 1(3), pp 311-320.

Baxter, P. \& Jack, S. 2008. Qualitative case study methodology: study design and implementation for novice researchers,

Bem, D. J. 1995. Writing a review article for Psychological Bulletin. Psychological Bulletin, 118(2), pp 172-177.

Bonazzi, L. \& Islam, S. M. N. 2007. Agency theory and corporate governance: A study of the effectiveness of board in their monitoring of the CEO. Journal of Modelling in Management, 2(1), pp 7-23.

Brouwer, G. E. 2011. Own motion investigation into ICT-enabled projects, Office, V. O. (Victoria, Australia).

Brown, C. \& Magill, S. 1994. Alignment of the IS functions with the enterprise: Toward a model of antecedents. Management Information Systems Quarterly, 18(4), pp 371-404.

Campion-Awwad, O., Hayton, A., L., S. \& Vuaran, M. 2014. The National Programme for IT in the NHS: A Case History. MPhil, Cambridge.

Cater-Steel, A., Toleman, M. \& Tan, W. G. 2006. Transforming IT service management - the ITIL impact. ACIS 2008. Paper presented at the ACIS 2008. http://aisel.aisnet.org/acis2006/81.

Cenfetelli, R.T. 2004. Inhibitors and Enablers as Dual Factor Concepts in Technology Usage, Journal of the Association for Information Systems, (5) 11-12, pp. 472-492.

Chaluverdi, R. \& Gupta, V. 2005. ERP Implementation Failure at HP. ICMR.

Christian, H. 2010. Seven habits of effective IT governance. Available: http://www.emeraldgrouppublishing.com/learning/management_thinking/articles/pdf/hagen_i t.pdf?PHPSESSID=g6u235aosboohc6vj5mvjf2f54 [Accessed 28 Feb 2016].

Coglianese, C., Healey, T. J., Keating, E. K. \& Michael, M. L. 2004. The role of government in corporate governance, USA: Harvard University.

Data, D. 2011. Ministry of social development - Kiosk review. Available: https://www.computerworld.co.nz/article/489137/dimension_data_kiosk_report_released/.

Davis, J. H., Schoorman, D. \& Donaldson, L. 1997. Toward a stewardship theory of management. The Academy of Management Review, 22(1), pp 20-47.

De Haes, S. \& Van Grembergen, W. Information Technology Governance Best Practices in Belgian Organisations. Proceedings of the 39th Annual Hawaii International Conference on System Sciences - Volume 08, 2006 Hawaii. 195.2. 
De Haes, S. \& Van Grembergen, W. 2010. An exploratory study into IT governance implementations and its impact on business/IT alignment. Information Systems Management, 26(1), pp 123-137.

Deloitte. 2012. Ministry of Social Development Independent Review of Information Systems Security. Available: https://www.nbr.co.nz/sites/default/files/images/deloitte-phase-2-final-report.pdf.

DeLone, W. H. \& McLean, E. R. 1992. Information systems success: The quest for the dependent variable. Information Systems Research, 3(1), pp 60-95.

Delone, W. H. \& McLean, E. R. 2003. The DeLone and McLean Model of Information Systems Success: A Ten-Year Update. Journal of Management Information Systems, 19(4), pp 9-30.

EDUCAUSE centre for applied research. 2008. IT governance maturity and context. Available: https://net.educause.edu/ir/library/pdf/erso805/rs/erso8053.pdf.

Esteves, J. \& Joseph, R. C. 2008. A comprehensive framework for the assessment of e-government projects. Government Information Quarterly, 25(118-132).

Fereday, I. \& Muir-Cochrane, E. 2016. Demonstrating Rigor Using Thematic Analysis: A Hybrid Approach of Inductive and Deductive Coding and Theme Development. International Journal of Qualitative Methods, 5(1), pp 80-92.

Fukuyama, F. 2013. What is Governance? . Available: http://dx.doi.org/10.2139/ssrn.2226592.

Gauld, R. \& Goldfinch, S. 2006. Dangerous enthusiasms: E-government, computer failure and information system development., Dunedin, New Zealand: Otago University Press.

Gole, T. \& Shinsky, G. 2013. Learning from failed ICT projects, Tobin, G.

Halonen, R., Acton, T., Golden, W. \& Conboy, K. 2009a. Delone \& McLean success model as a descriptive tool in evaluating a virtual learning environment. International Conference on Organizational Learning, Knowledge and Capabilities (OLKC 2009). Amsterdam, the Netherlands.

Hellsten, S.-M. \& Karkove, M. 2006. The DeLone and McLean Model of Information Systems SuccessOriginal and Updated Models. SIGCHI Conference.

ITGI. 2007. COBIT 4.1. Illinois: ITGI.

Kaplan, R. S. 2010. Conceptual foundations of the balanced scorecard. Available: http://www.hbs.edu/faculty/Publication\%20Files/10-074.pdf.

Kaplan, R. S. \& Norton, D. P. 2004. Measuring the strategic readiness of intangible assets. Harvard Business Review, 82(2), pp 52-63.

Krigsman, M. 2008. <h1 style="margin-top:ocm;margin-right:ocm;margin-bottom:7.5pt;marginleft:ocm;mso-line-height-alt:12.5pt;background:white"> Qantas Airways: a perfect storm for IT failure? Available: http://www.zdnet.com/article/qantas-airways-a-perfect-storm-for-it-failure/.

Larcker, B. F. \& Tayan, B. 2008a. Models of corporate governance: Who's the fairest of them all? Harvard Business Review, 33.

Laudon, K. C. \& Laudon, J. P. 2014. Management Information Systems: Pearson Education Limited.

Lovelock, J. D., Hale, K., Lewis, B., Hahn, W. L., Dornan, M., Atwal, R., Graham, C. \& Gupta, N. 2016. Forecast Alert: IT spending, worldwide, 2016 Update. Available: http://www.gartner.com/document/3365822? $\mathrm{ref}=$ solrAll\&refval=171692296\&qid=045cfc67a2fce db47ea1cc373a450684 [Accessed 16 July 2016].

McColgan, P. 2001. Agency theory and corporate governance: a review of the literature from a UK perspective. http://citeseerx.ist.psu.edu/viewdoc/download?doi=10.1.1.202.286\&rep=rep1\&type=pdf.

McLellan, C. 2014. IT budgeting in 2015: What the surveys tell us. Available: http://www.zdnet.com/article/it-budgeting-in-2015-what-the-surveys-tell-us/ [Accessed 16 January 2016].

Moher, D., Liberati, A., Telzlaff, J. \& Altman, D. G. 2009. Preferred Reporting Items for Systematic Reviews and Meta-Analyses: The PRISMA Statement. PloS Med Journal, 6(7).

Myers, J. 2012. Strategic data management in the era of Big Data.

NZ Government. 2013. Report of the ministerial inquiry into the NOVOPAY project, Government, N. Z. (Wellington, New Zealand).

Okoli, C. 2015. A Guide to Conducting a Standalone Systematic Literature Review. Communications of the Association for Information Systems, 37(1), Article 43.

Prasad, A., Green, P. \& Heales, J. 2008. Towards a better understanding of information technology, (Brisbane).

Prasad, A., Heales, J. \& Green, P. 2010. A capabilities-based approach to obtaining a deeper understanding of information technology governance effectiveness: Evidence from IT steering committees. International Journal of Accounting Information Systems, 11(3), pp 214-232.

Ramgovind, S., Eloff, M. \& Smith, E. 2015. The management of cloud security in cloud computing. uir.unisa.ac.za

[Online].

Available: 
http://uir.unisa.ac.za/xmlui/bitstream/handle/10500/3883/ramgovind.pdf?sequence=1 [Accessed August 16].

Ritchie, J. \& Lewis, J. 2003. Qualitative Research Practice: a Guide for Social Science Students and Researchers, Thousand Oaks, California: SAGE Publications, Inc.

SFIA Foundation. 2015. Skills Framework for Information Age. SFIA Foundation.

Stake, R. 2006. Multiple case study analysis, London: The Gulford Press.

Swain, J. 2018. A hybrid approach to thematic analysis in qualitative research: Using a practical example. SAGE Research Methods Cases. doi:10.4135/9781526435477

Van Grembergen, W. 2004. Strategies for information technology governance: Idea Group Publisher.

Van Grembergen, W. \& De Haes, S. 2009. Enterprise governance of information technology: Springer.

Webster, J. \& Watson, R. T. 2002. Analyzing past to prepare for the future: Writing a literature review. MIS Quarterly, 26(2), pp 13-22.

Weill, P. 2004. Don't just lead, govern: How top performing firms govern IT. MIS Quarterly Executive, 3(1), pp 1-14.

Weill, P. \& Ross, J. 2004a. IT governance on one page. Available: https://papers.ssrn.com/sol3/papers.cfm?abstract_id=664612.

Weill, P. \& Ross, J. 2004b. IT Governance: How Top Managers Manage IT Decision Rights for Superior Results, Boston: Harvard Business School Press.

Weill, P. \& Vitale, M. 2002. What IT infrastructure capabilities are needed to implement E-business models? MIS Quarterly Executive, 1(1), pp 17-34.

Williams, P. A. 2012. Optimising value creation from IT investments. Available: http://www.isaca.org/Knowledge-Center/Research/Documents/Outsourcing.pdf [Accessed September 26, 2015].

Wu, S. P., Straub, D. W. \& Liang, T. 2015. How information technology governance mechanisms and strategic alignment influence organizational performance: Insights from a matched survey of business and IT managers. MIS Quarterly, 39(2), pp 497-518.

Yin, R. K. 2011. Qualitative Research from Start to Finish: The Guilford Press.

Zaied, A. N. H. 2012. An integrated success model for evaluating information system in public sectors. Journal of Emerging Trends in Computing and Information Sciences, 3(6), pp.

Zuber, G. (2008). Qantas Engineering - transforming Maintenance, Repair and Operations with Project Marlin and Holocentric. Retrieved from https://www.holocentric.com/s/QE-Short.pdf 